\title{
On-pump intracardiac echocardiography during septal myectomy for hypertrophic cardiomyopathy
}

David M. Williams, MD, ${ }^{\mathrm{a}}$ Robert G. Nampi, MD, ${ }^{\mathrm{b}}$ Muhamed Saric, MD, PhD, ${ }^{\mathrm{c}}$ Eugene A. Grossi, MD, Mark V. Sherrid, MD, ${ }^{c}$ and Daniel G. Swistel, MD ${ }^{\mathrm{a}}$

From the ${ }^{\mathrm{a}}$ Department of Cardiothoracic Surgery, ${ }^{\mathrm{b}}$ Division of Cardiothoracic Anesthesiology, and ${ }^{\mathrm{c}}$ Division of Cardiology, Hypertrophic Cardiomyopathy Program, NYU Langone Health, New York University School of Medicine, New York, NY.

Disclosures: Ultrasound probes and console were provided at no cost by Hitachi Healthcare Americas (Twinsburg, Ohio). The authors reported no conflicts of interest.

The Journal policy requires editors and reviewers to disclose conflicts of interest and to decline handling or reviewing manuscripts for which they may have a conflict of interest. The editors and reviewers of this article have no conflicts of interest.

Read at the 45th Annual Meeting of the Western Thoracic Surgical Association, Olympic Valley, California, June 26-29, 2019.

Received for publication Dec 3, 2019; revisions received Dec 3, 2019; accepted for publication Jan 3, 2020; available ahead of print Feb 26, 2020.

Address for reprints: Daniel G. Swistel, MD, Department of Cardiothoracic Surgery, Hypertrophic Cardiomyopathy Program, NYU Langone Health, New York University School of Medicine, 530 First Ave, Suite 9V, New York, NY 10016 (E-mail: daniel.swistel@nyulangone.org).

JTCVS Techniques 2020;2:60-6

2666-2507

Copyright (C 2020 The Authors. Published by Elsevier Inc. on behalf of The American Association for Thoracic Surgery. This is an open access article under the CC BY-NC-ND license (http://creativecommons.org/licenses/bync-nd/4.0/).

https://doi.org/10.1016/j.xjtc.2020.01.027

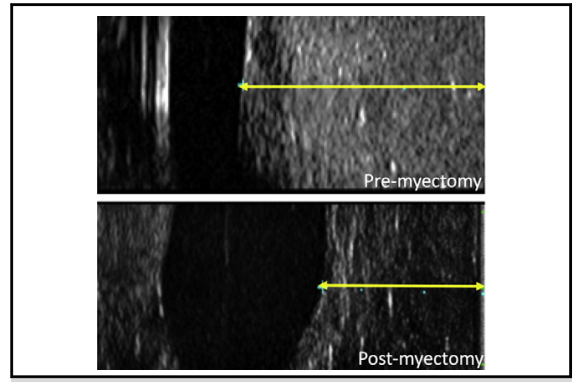

On-pump intracardiac echocardiography before and after septal myectomy.

CENTRAL MESSAGE

On-pump intracardiac echocardiography correlates with established imaging to aid in septal myectomy. Further studies are needed to examine the clinical influence of this technique.

See Commentaries on pages 67 and 68 .

Surgical septal myectomy is the gold standard to relieve the left ventricular outflow tract obstruction (LVOTO) associated with hypertrophic cardiomyopathy (HCM). ${ }^{1}$ Real-time measurements of the interventricular septal thickness are crucial during septal myectomy to avoid

creating a ventricular septal defect while resecting enough myocardium to relieve the LVOTO. We therefore revisited a methodology initially described in 1977 with rudimentary

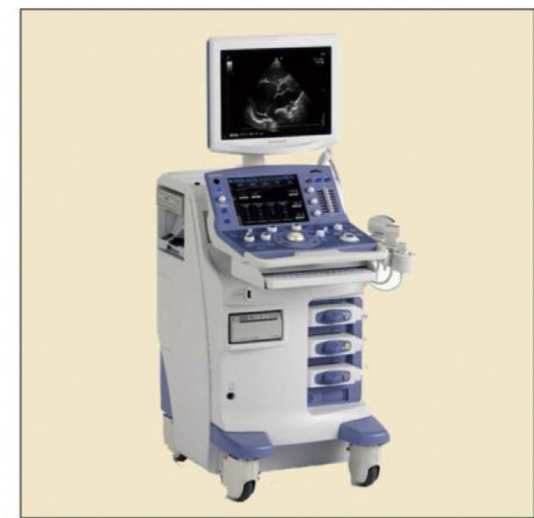

A

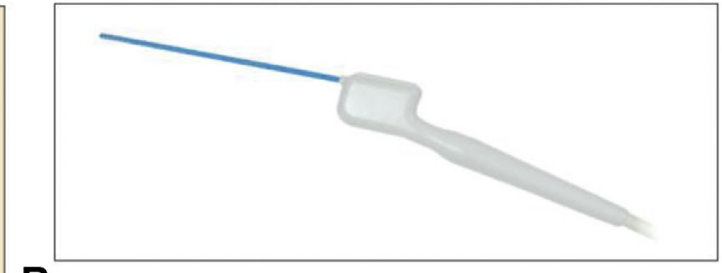

B

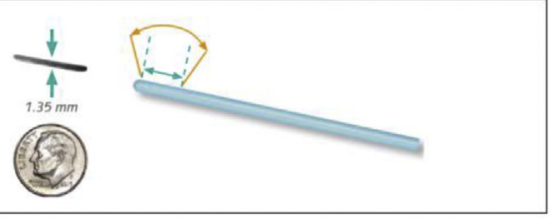

C

FIGURE 1. A, On-pump intraoperative echocardiography console. B and C, Probe. With a diameter just larger than the thickness of 2 small coins, the blue portion of the probe is thin enough to be inserted transaortically into the heart and placed against the basilar interventricular septum. Images are projected onto the console and measurements of the interventricular septum are taken. The blue hashed lines and orange arc demonstrate the $10 \mathrm{~mm}, 60^{\circ}$ trapezoidal scan width at the distal end of the probe. Images reproduced with permission from Hitachi Healthcare Americas, Twinsburg, Ohio. 


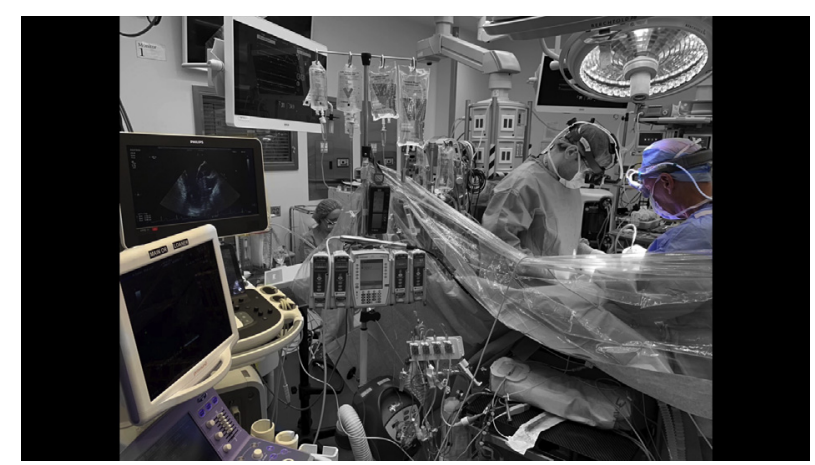

VIDEO 1. Instructional video describing the operating room setup and technical aspects of performing on-pump intracardiac echocardiography. Video available at: https://www.jtcvs.org/article/S2666-2507(20)30099-7/ fulltext.

ultrasound technology using a modern ultrasound probe that we call on-pump intracardiac echocardiography (OPIE). ${ }^{2}$ The aim of the current study was to examine the comparability of OPIE to established imaging modalities.

\section{METHODS}

This was a prospective observational feasibility study to examine the correlation between intracardiac echocardiography, transesophageal echocardiography (TEE), and transthoracic echocardiography (TTE) during 10 consecutive septal myectomies for HCM refractory to medical management (Appendix 1). OPIE was performed with a specialized ultrasound probe (Figure 1) placed transaortically onto the anterobasilar septum before and after septal myectomy. ${ }^{3}$ Video 1 describes the operating room setup and technical aspects of the procedure. We analyzed the comparability of TTE, TEE, and OPIE measurements of septal thickness both before and after septal myectomy (Appendix 2). The patients provided informed consent for the publication of the study data.

\section{RESULTS}

Representative OPIE and TEE images are shown in Figure 2. Demographic, procedural, gradient, and septal thickness data in 10 patients undergoing septal myectomy for hypertrophic cardiomyopathy are shown in Table 1 . The median provoked gradients were reduced from 100 $\mathrm{mm} \mathrm{Hg}$ (interquartile range, $77.5-125 \mathrm{~mm} \mathrm{Hg}$ ) to $4.5 \mathrm{~mm}$ $\mathrm{Hg}$ (interquartile range, 4.0-6.75 $\mathrm{mm} \mathrm{Hg}$ ). Median premyectomy septal thickness as measured by TTE, TEE, and OPIE were $16.0 \mathrm{~mm}$ (interquartile range 15.0-22.0 $\mathrm{mm}$ ), $21.5 \mathrm{~mm}$ (interquartile range, 20.0-26.75 mm), and $23.0 \mathrm{~mm}$ (interquartile range, $20.0-25.25 \mathrm{~mm}$ ), respectively. Median postmyectomy septal thickness as measured by TTE, TEE, and OPIE were $13.5 \mathrm{~mm}$ (interquartile range, $11.25-14.0 \mathrm{~mm}$ ), $15.0 \mathrm{~mm}$ (interquartile range, 13.25$16.75 \mathrm{~mm}$ ), and $16.0 \mathrm{~mm}$ (interquartile range, 12.25$16.75 \mathrm{~mm}$ ), respectively. Detailed results are available in Appendix 3.

\section{On-pump intracardiac echocardiography}

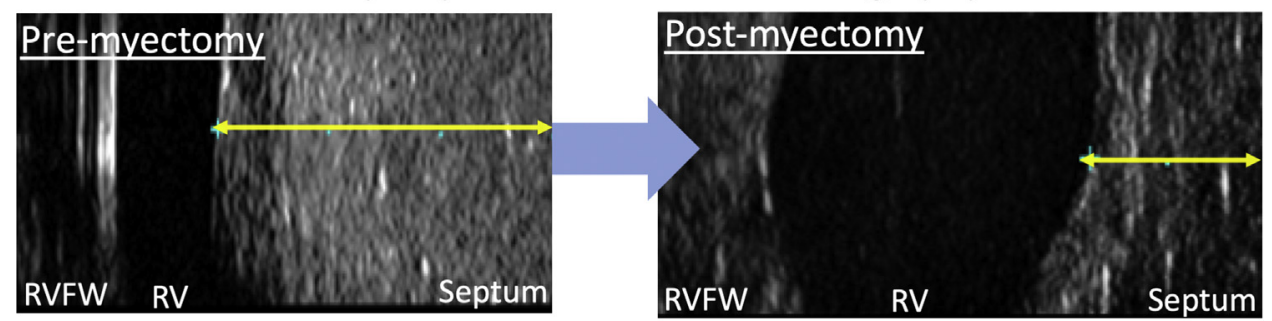

Transesophageal echocardiography

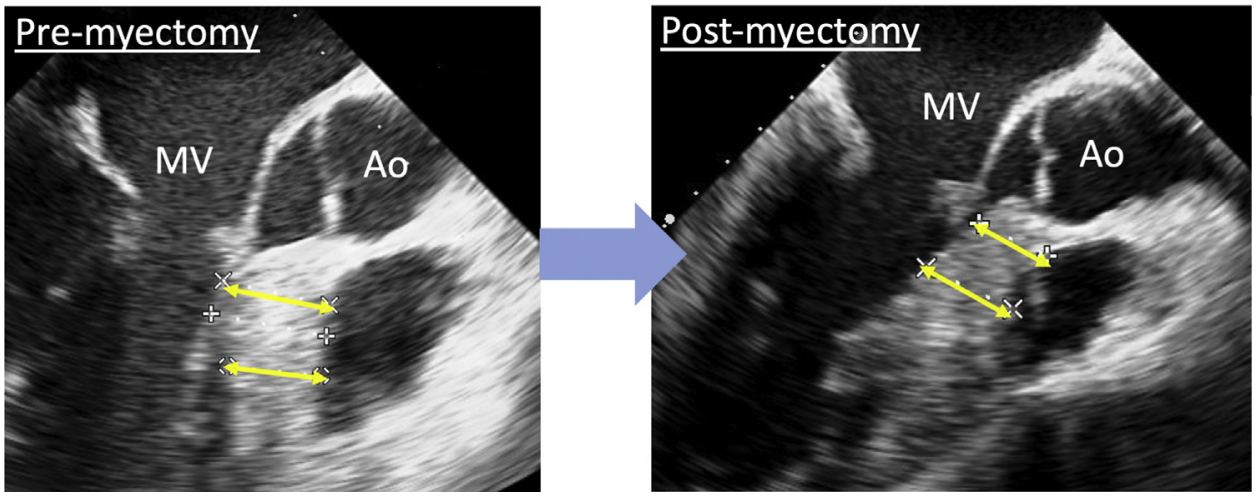

FIGURE 2. Representative images of the anterior basal septum as shown by on-pump intraoperative echocardiography (top row) and traditional transesophageal echocardiography (bottom row). Yellow lines represent septal thickness that was measured and compared between to the imaging modalities. $R V F W$, Right ventricular free wall; $R V$, right ventricle; $M V$, mitral valve; $A o$, aorta. 
TABLE 1. Demographic, procedural, gradient, and septal thickness data for 10 patients undergoing septal myectomy for hypertrophic cardiomyopathy

\begin{tabular}{|c|c|c|c|c|c|}
\hline Patient sex & Age (y) & Procedures & $\begin{array}{l}\text { Provoked LVOTO } \\
\text { gradient (mm Hg) }\end{array}$ & $\begin{array}{l}\text { Premyectomy septal } \\
\text { thickness }(\mathbf{m m})\end{array}$ & $\begin{array}{l}\text { Postmyectomy septal } \\
\text { thickness }(\mathbf{m m})\end{array}$ \\
\hline Male & 57 & $\begin{array}{l}\text { Extended septal myectomy, } \\
\text { complex mitral valvuloplasty }\end{array}$ & $\begin{array}{l}\text { Premyectomy: } 125 \\
\text { Postmyectomy: } 19 \\
\text { \% decrease: } 84.8\end{array}$ & $\begin{array}{l}\text { TTE: } 17 \\
\text { TEE: } 17 \\
\text { OPIE: } 19\end{array}$ & $\begin{array}{l}\text { TTE: } 11 \\
\text { TEE: } 14 \\
\text { OPIE: } 13\end{array}$ \\
\hline Male & 80 & $\begin{array}{l}\text { Extended septal myectomy, } \\
\text { complex mitral valvuloplasty, } \\
\text { AVR, CABG }\end{array}$ & $\begin{array}{l}\text { Premyectomy: } 185 \\
\text { Postmyectomy: } 6 \\
\% \text { decrease: } 96.8\end{array}$ & $\begin{array}{l}\text { TTE: } 15 \\
\text { TEE: } 21 \\
\text { OPIE: } 23\end{array}$ & $\begin{array}{l}\text { TTE: } 13 \\
\text { TEE: } 15 \\
\text { OPIE: } 16\end{array}$ \\
\hline Female & 50 & $\begin{array}{l}\text { Extended septal myectomy, } \\
\text { complex mitral valvuloplasty }\end{array}$ & $\begin{array}{l}\text { Premyectomy: } 125 \\
\text { Postmyectomy: } 8 \\
\% \text { decrease: } 93.6\end{array}$ & $\begin{array}{l}\text { TTE: } 15 \\
\text { TEE: } 22 \\
\text { OPIE: } 23\end{array}$ & $\begin{array}{l}\text { TTE: } 12 \\
\text { TEE: } 15 \\
\text { OPIE: } 16\end{array}$ \\
\hline Male & 63 & $\begin{array}{l}\text { Extended septal myectomy, } \\
\text { complex mitral valvuloplasty }\end{array}$ & $\begin{array}{l}\text { Premyectomy: } 59 \\
\text { Postmyectomy: } 4 \\
\text { \% decrease: } 93.2\end{array}$ & $\begin{array}{l}\text { TTE: } 14 \\
\text { TEE: } 20 \\
\text { OPIE: } 20\end{array}$ & $\begin{array}{l}\text { TTE: } 14 \\
\text { TEE: } 12 \\
\text { OPIE: } 12\end{array}$ \\
\hline Male & 62 & $\begin{array}{l}\text { Extended myectomy, complex } \\
\text { mitral valvuloplasty, maze, } \\
\text { LAA clip }\end{array}$ & $\begin{array}{l}\text { Premyectomy: } 100 \\
\text { Postmyectomy: } 2 \\
\% \text { decrease: } 98.0\end{array}$ & $\begin{array}{l}\text { TTE: } 24 \\
\text { TEE: } 29 \\
\text { OPIE: } 28\end{array}$ & $\begin{array}{l}\text { TTE: } 17 \\
\text { TEE: } 18 \\
\text { OPIE: } 17\end{array}$ \\
\hline Male & 34 & $\begin{array}{l}\text { Extended septal myectomy, } \\
\text { complex mitral valvuloplasty }\end{array}$ & $\begin{array}{l}\text { Premyectomy: } 72 \\
\text { Postmyectomy: } 5 \\
\text { Percent decrease: } 93.1\end{array}$ & $\begin{array}{l}\text { TTE: } 26 \\
\text { TEE: } 28 \\
\text { OPIE: } 26\end{array}$ & $\begin{array}{l}\text { TTE: } 14 \\
\text { TEE: } 19 \\
\text { OPIE: } 19\end{array}$ \\
\hline Female & 58 & $\begin{array}{l}\text { Extended myectomy, complex } \\
\text { mitral valvuloplasty, LAA clip }\end{array}$ & $\begin{array}{l}\text { Premyectomy: } 94 \\
\text { Postmyectomy: } 7 \\
\text { \% decrease: } 92.6\end{array}$ & $\begin{array}{l}\text { TTE: } 14 \\
\text { TEE: } 19 \\
\text { OPIE: } 17\end{array}$ & $\begin{array}{l}\text { TTE: } 11 \\
\text { TEE: } 13 \\
\text { OPIE: } 12\end{array}$ \\
\hline Female & 62 & $\begin{array}{l}\text { Extended septal myectomy, } \\
\text { complex mitral valvuloplasty }\end{array}$ & $\begin{array}{l}\text { Premyectomy: } 56 \\
\text { Postmyectomy: } 3 \\
\text { \% decrease: } 94.5\end{array}$ & $\begin{array}{l}\text { TTE: } 15 \\
\text { TEE: } 20 \\
\text { OPIE: } 20\end{array}$ & $\begin{array}{l}\text { TTE: } 10 \\
\text { TEE: } 12 \\
\text { OPIE: } 11\end{array}$ \\
\hline Female & 57 & $\begin{array}{l}\text { Extended septal myectomy, } \\
\text { complex mitral valvuloplasty }\end{array}$ & $\begin{array}{l}\text { Premyectomy: } 180 \\
\text { Postmyectomy: } 4 \\
\text { \% decrease: } 97.8\end{array}$ & $\begin{array}{l}\text { TTE: } 22 \\
\text { TEE: } 26 \\
\text { OPIE: } 23\end{array}$ & $\begin{array}{l}\text { TTE: } 14 \\
\text { TEE: } 16 \\
\text { OPIE: } 16\end{array}$ \\
\hline Male & 37 & $\begin{array}{l}\text { Extended septal myectomy, } \\
\text { complex mitral valvuloplasty }\end{array}$ & $\begin{array}{l}\text { Premyectomy: } 100 \\
\text { Postmyectomy: } 4 \\
\% \text { decrease: } 96.0\end{array}$ & $\begin{array}{l}\text { TTE: } 22 \\
\text { TEE: } 27 \\
\text { OPIE: } 26\end{array}$ & $\begin{array}{l}\text { TTE: } 16 \\
\text { TEE: } 17 \\
\text { OPIE: } 17\end{array}$ \\
\hline & & & $\begin{array}{l}\text { Premyectomy: } 100(77.5-125)^{*} \\
\text { Postmyectomy: } 4.5(4.0-6.75)^{*} \\
\% \text { decrease: } 94.1(93.3-96.6)^{*}\end{array}$ & $\begin{array}{l}\text { TTE: } 16(15.0-22.0)^{*} \\
\text { TEE: } 21.5(20.0-26.75)^{*} \\
\text { OPIE: } 23(20.0-25.25)^{*}\end{array}$ & $\begin{array}{l}\text { TTE: } 13.5(11.25-14.0)^{*} \\
\text { TEE: } 15(13.25-16.75)^{*} \\
\text { OPIE: } 16(12.25-16.75)^{*}\end{array}$ \\
\hline
\end{tabular}

LVOTO, Left ventricular outflow tract obstruction; TTE, transthoracic echocardiography; TEE, transesophageal echocardiography; OPIE, on-pump intracardiac echocardiography; $A V R$, aortic valve replacement; $C A B G$, coronary artery bypass graft; $L A A$, left atrial appendage. *Value is presented as median (interquartile range).

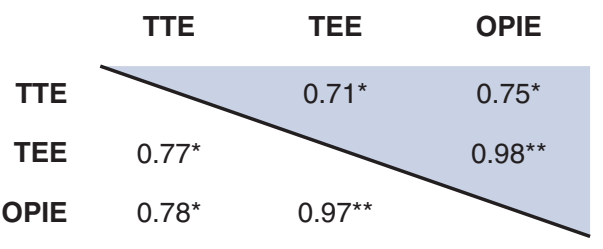

FIGURE 3. Spearman correlation of all 3 imaging modalities premyectomy (white background to the left of the diagonal line) and postmyectomy (shaded background to the right of the diagonal line). TTE, Transthoracic echocardiography; TEE, transesophageal echocardiography; OPIE, onpump intracardiac echocardiography. $* P<.01$. $* * P<.001$.
Spearman correlations of measured septal thickness pre- and postmyectomy are shown in Figure 3 (scatter plots available in Figure 4). Measurements from all 3 imaging techniques were significantly correlated both pre- and postmyectomy with the highest correlation being between TEE and OPIE both pre- and postmyectomy (premyectomy: rho, $0.97 ; P<.001$ and postmyectomy: rho, $0.98 ; P<.001$ ). Bland-Altman plot analysis demonstrates that only the TEE and OPIE measurements could be considered interchangeable without any adjustments (Figure 5). 

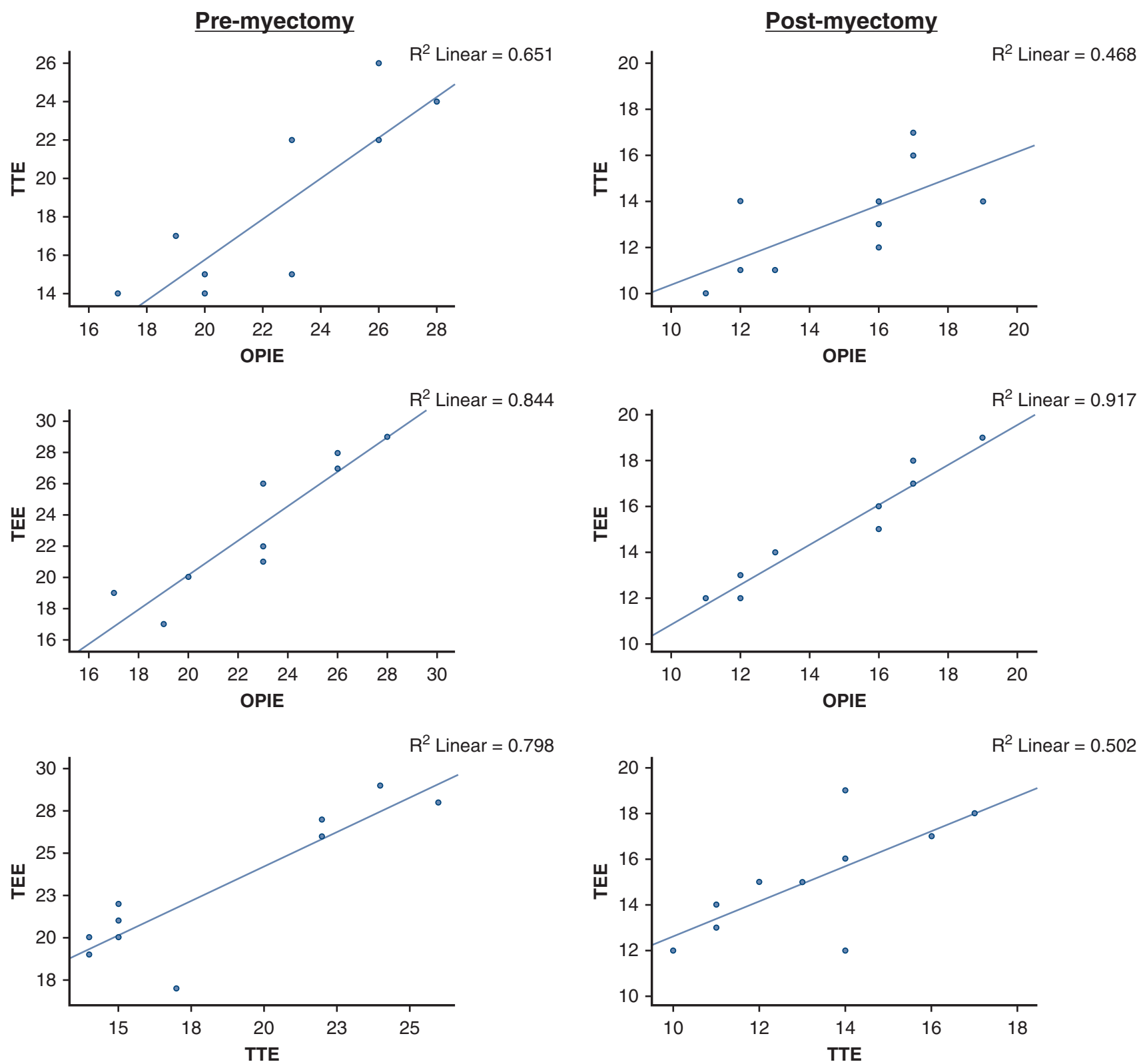

FIGURE 4. Scatter plots demonstrating the correlations of all imaging modalities in the pre- and postmyectomy setting. TTE, Transthoracic echocardiography; OPIE, on-pump intracardiac echocardiography; TEE, transesophageal echocardiography.

TTE correlated poorly with the other measurement modalities when estimating the amount of resected septal myocardium by subtracting the postmyectomy ventricular septal thickness from the premyectomy ventricular septal thickness (Figure 6,A). The measurements of pre- and postmyectomy septal wall thickness correlated highly between the surgeon's estimate, TEE, and OPIE. The measurements of pre- and postmyectomy septal wall thickness correlated less robustly between pathologic analysis, TEE, and TTE, although most of these relationships still met statistical significance (Figure 6, B).
During 1 myectomy of a $1.7-\mathrm{cm}$ basilar interventricular septum, OPIE measurements suggested that there were $3 \mathrm{~mm}$ of remaining septum amenable to resection. However, given the thin nature of the initial septum, we wished to confirm these findings with TEE. The patient was therefore taken off cardiopulmonary bypass and a repeat TEE was performed. The repeat TEE confirmed the OPIE measurements so the heart was rearrested and additional myectomy was safely performed. The final septal thickness and gradient measurements after the additional myectomy were included for analysis. 

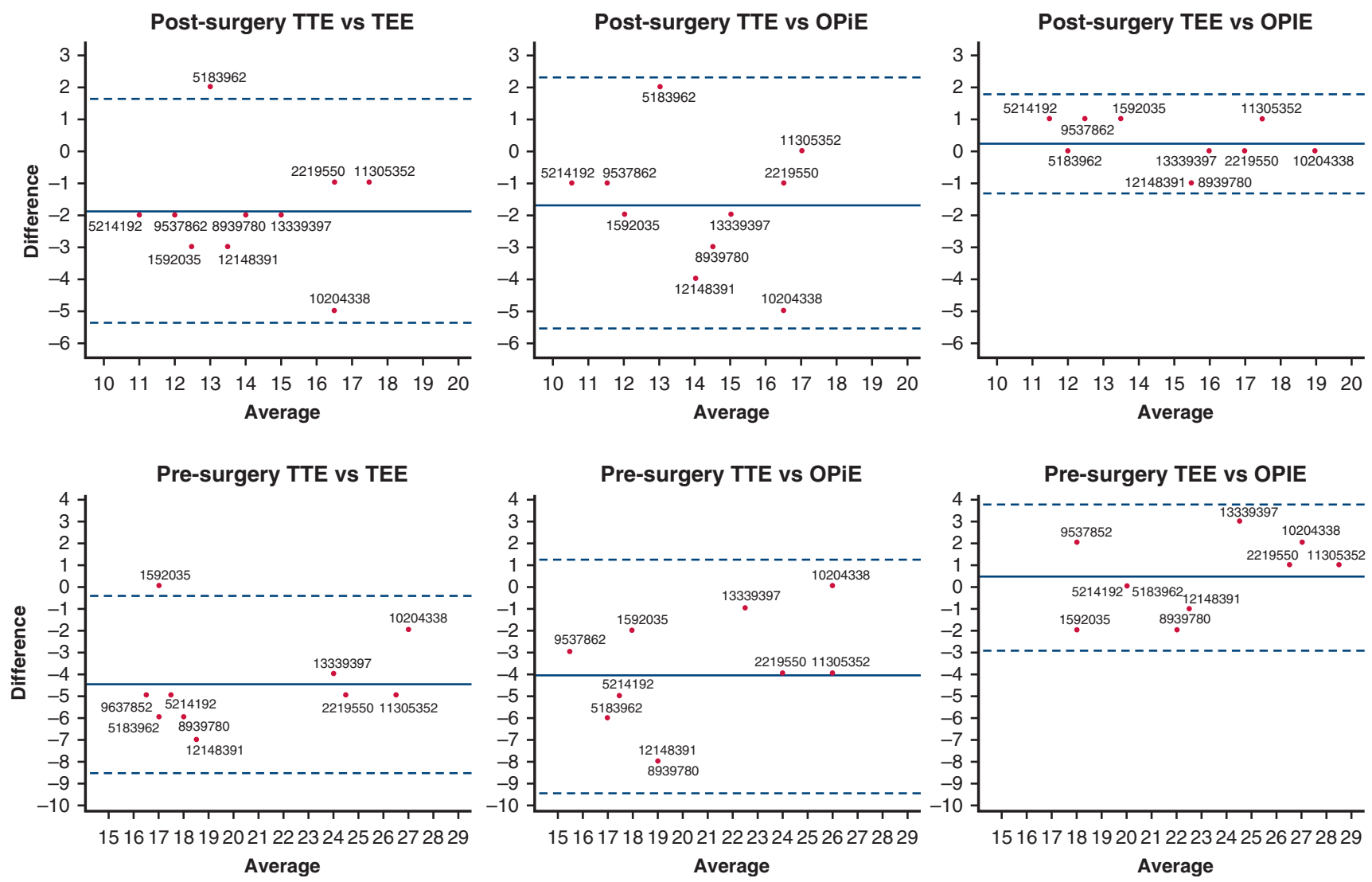

FIGURE 5. Pre- and postmyectomy Bland Altman plots demonstrate that only the transesophageal echocardiography (TEE) and on-pump intracardiac echocardiography $(O P I E)$ measurements can be considered interchangeable without any adjustments, because all of the differences fall within the $95 \%$ limits of agreement and the $95 \%$ confidence interval of the mean difference includes 0 both before and after myectomy. TTE, Transthoracic echocardiography.

\begin{tabular}{ccccc} 
& \multicolumn{1}{c}{ TTE } & & \\
TEE & 0.57 & TEE & & \\
\cline { 2 - 3 } $\begin{array}{c}\text { OPIE } \\
\begin{array}{c}\text { Surgeon } \\
\text { estimate }\end{array}\end{array}$ & 0.14 & $0.74^{*}$ & OPIE & \\
\cline { 2 - 3 } $\begin{array}{c}\text { Pathologic } \\
\text { analysis }\end{array}$ & 0.48 & $0.76^{*}$ & 0.40 & $\begin{array}{c}\text { Surgeon } \\
\text { estimate }\end{array}$ \\
\cline { 2 - 3 } & 0.46 & 0.20 & $0.73^{*}$
\end{tabular}

A

\begin{tabular}{|c|c|c|c|}
\hline & & $\begin{array}{l}\text { Surgeon } \\
\text { estimate }\end{array}$ & $\begin{array}{c}\text { Pathologic } \\
\text { analysis }\end{array}$ \\
\hline \multirow{3}{*}{ Pre-myectomy } & TTE & $0.75^{\star}$ & 0.62 \\
\hline & TEE & $0.91^{* *}$ & $0.64^{*}$ \\
\hline & OPIE & $0.88^{\star *}$ & $0.65^{*}$ \\
\hline \multirow{3}{*}{ Post-myectomy } & TTE & $0.86^{* *}$ & $0.75^{\star}$ \\
\hline & TEE & $0.87^{* *}$ & $0.68^{*}$ \\
\hline & OPIE & $0.89^{* *}$ & $0.70^{*}$ \\
\hline
\end{tabular}

FIGURE 6. A, Spearman correlations of the amount of muscle resected as determined by subtracting the postmyectomy ventricular septal thickness from the premyectomy ventricular septal thickness when measured by transthoracic echocardiography (TTE), transesophageal echocardiography (TEE), on-pump intracardiac echocardiography (OPIE), surgeon estimate, and pathologic analysis. B, Spearman correlations of pre- and postmyectomy septal thickness between TTE, TEE, OPIE, surgeon estimate, and pathologic analysis. $* P<.05$. $* * P<.01$. 


\section{CONCLUSIONS}

OPIE correlates significantly with established imaging techniques to aid in septal myectomy for patients with HCM. Further studies are needed to examine the clinical influence of using OPIE as an adjunct during myectomy for HCM, especially in those patients with a LVOTO in the setting of a thin interventricular septum.

The authors thank Elizabeth Pirraglia, MA, statistical consultant.

\section{References}

1. Gersh BJ, Maron BJ, Bonow RO, Bonow RO, Dearani JA, Fifer MA, et al. 2011 ACCF/AHA guideline for the diagnosis and treatment of hypertrophic cardiomyopathy: executive summary: a report of the American College of Cardiology Foundation/American Heart Association task force on practice guidelines. $J$ Am Coll Cardiol. 2011;58:2703-38.

2. Syracuse DC, Gaudini VA, Kastl DG, Henry WL, Morrow AG. Intraoperative, intracardiac echocardiography during left ventricumyotomy and myectomy for hypertrophic subaortic stenosis. Cardiovasc Surg. 1977;58: 23-7.

3. UST-5311 Pituitary Guidance Transducer [package insert]. Twinsburg, OH: Hitachi Healthcare Americas; 2017. 


\section{APPENDIX 1. DETAILED METHODS}

Each patient was cared for preoperatively, intraoperatively, and postoperatively by the same cardiologist, cardiothoracic surgeon, and cardiac anesthesiologist. All patients had outpatient transthoracic stress echocardiograms performed before and after myectomy from which left ventricular outflow tract gradient data were taken. At surgery, septal thickness measurements were made with transesophageal echocardiography before the initiation of cardiopulmonary bypass, before and after myectomy, and after cessation of cardiopulmonary bypass. Pre- and postmyectomy septal measurements were jointly analyzed by the hypertrophic cardiomyopathy cardiologist, surgeon, and anesthesiologist.

Septal myectomies were performed via a median sternotomy approach with central arterial and venous cannulation; the left ventricle was vented through the right superior pulmonary vein. The heart was arrested with del Nido cardioplegia solution and an extended aortotomy was performed. To obtain on-pump intracardiac echocardiography (OPIE) imaging, the right ventricle was briefly backfilled with blood to create an interface between the blood and myocardium. Without backfilling, the collapsed free wall of the right ventricle in the arrested heart obscures the true depth of the septum. The OPIE probe (Model UST-5311; Hitachi Healthcare Americas, Twinsburg, Ohio) (Figure 1) was introduced through the aortotomy and placed onto the anterior basal septum. Septal thickness was then measured at the center of the proposed muscular resection and recorded by the cardiac anesthesiologist. Septal myectomy with complex mitral valvuloplasty was performed. Complex mitral valvuloplasty is an umbrella term we use to describe interventions on the mitral subvalvular apparatus during septal myectomy that we describe elsewhere. ${ }^{1}$ Complex mitral valvuloplasty typically refers to resection of a residual anterior mitral valve leaflet (most commonly A2), resection of a secondary residual chord, resection of a papillary muscle head, or a combination of these procedures. At the conclusion of the myectomy, the OPIE probe was reintroduced into the heart and the anterior basal septal thickness was again measured. All measurements were taken by the same cardiothoracic surgeon and were reviewed in real time by the hypertrophic cardiomyopathy cardiologist. The surgeon also estimated the thickness of the resected septal muscle specimen.

\section{Reference}

1. Swistel DG, Derose JJ Jr, Sherrid MV. Management of patients with complex hypertrophic cardiomyopathy: resection/plication/release. Oper Techn Thorac Cardiovasc Surg. 2004;9:261-7.

\section{APPENDIX 2. DESCRIPTIVE STATISTICS}

Pre- and postmyectomy left ventricular outflow tract obstruction gradient and septal thickness data are presented as median (interquartile range). The Kolmogorov-Smirnov test was used to test if the variables were normally distributed. Premyectomy transthoracic echocardiography and postmyectomy on-pump intracardiac echocardiography data were found to be significantly different than the normal distribution, so Spearman (nonparametric) correlations were used to test the association between measurements. Bland-Altman plots were used to graphically assess the pairwise agreement between the measurement techniques. ${ }^{1} \mathrm{We}$ subtracted the postmyectomy septal thickness from the premyectomy septal thickness as measured by the 3 imaging modalities to infer the size of the myocardium that was resected. The surgeon's estimate of the amount of septum removed and the thickness as determined by the pathologist were additionally recorded.

\section{References}

1. Altman DG, Bland JM. Measurement in medicine: the analysis of method comparison studies. Statistician. 1983;32:307-17.

\section{APPENDIX 3. DETAILED RESULTS}

Ten patients underwent extended septal myectomies between November 2017 and February 2018. The mean age was $56.0 \pm 13.3$ years and $60 \%$ were men. Most patients underwent extended septal myectomies with complex mitral valvuloplasties, although 3 underwent additional concomitant procedures. The provoked gradients were reduced from a median of $100 \mathrm{~mm} \mathrm{Hg}$ (interquartile range, 77.5-125 mm $\mathrm{Hg}$ ) to $4.5 \mathrm{~mm} \mathrm{Hg}$ (interquartile range, $4.0-6.75 \mathrm{~mm} \mathrm{Hg}$ ) or a median decrease in left ventricular outflow tract obstruction gradient of $94.1 \%$ (interquartile range, $93.3 \%-96.6 \%$ ) from preoperative measurements. Those patients with residual gradients were believed to have remaining septum that was too thin to resect further. None of the patients had residual systolic anterior motion and all of the patients had residual gradients $<30 \mathrm{~mm} \mathrm{Hg}$, which is the commonly accepted marker of severe left ventricular outflow tract obstruction. On-pump intracardiac echocardiography measurements added less than 5 minutes to the aortic crossclamp time. There were no postoperative ventricular septal defects. 